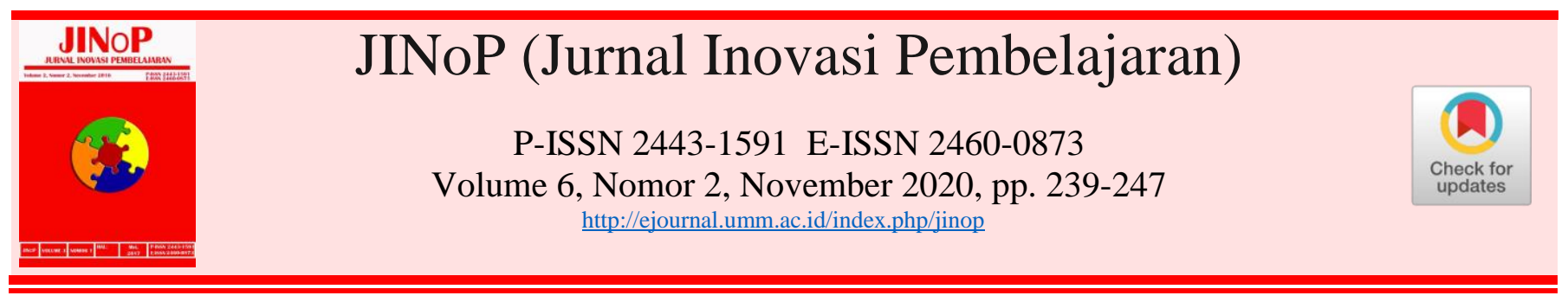

\title{
Aplikasi model inkuiri terbimbing berbantuan LKPD untuk meningkatkan keterampilan proses sains pada materi kalor
}

\author{
Siska Dewi Aryani ${ }^{1 *}$ \\ ${ }^{1}$ Program Studi Pendidikan Fisika, Fakultas Keguruan dan Ilmu Pendidikan, Universitas Siliwangi, \\ Indonesia \\ siskadewi.aryani18@gmail.com ${ }^{1 *}$ \\ *Penulis Koresponden
}

\begin{abstract}
ABSTRAK
Penulisan ini dilatar belakangi oleh pola pembelajaran yang ditekankan saat ini selain menuntut pembelajaran yang mengedepankan kemampuan berpikir kritis juga pembelajaran harus menggunakan pendekatan saintifik. Kebanyakan peserta didik menganggap bahwa materi fisika terutama subkonsep kalor adalah materi abstrak. Untuk itu, perlu ada aplikasi dalam pembelajaran yaitu dengan mengaplikasikan model inkuiri terbimbing berbantuan LKPD agar peserta didik dapat meningkatkan keterampilan proses sainsnya. Tujuan penelitian ini yaitu mendeskripsikan aplikasi model inkuiri terbimbing berbantuan LKPD untuk meningkatkan keterampilan proses sains pada materi kalor. Metode yang digunakan dalam penulisan ini yaitu dengan studi kepustakaan dengan mengkaji beberapa literatur untuk dianalisis dan dibuat kesimpulan. Hasil penulisan menunjukkan bahwa model inkuiri terbimbing berbantuan LKPD untuk peserta didik dapat menjadi solusi dari permasalahan yang ditemui dalam meningkatkan keterampilan proses sains peserta didik di kelas. Model inkuiri terbimbing berbantuan LKPD diaplikasikan kepada peserta didik di Sekolah Menengah Atas dengan beberapa langkah antara lain; peserta didik diberikan masalah untuk dipecahkan, masalah diberikan dalam bentuk LKPD, selanjutnya melakukan proses analisis dan diskusi untuk menemukan solusi dari masalah yang ditemukan, setelah itu peserta didik melakukan presentasi kepada kelompok lain dengan LKPD yang sudah di isi selama proses pembelajaran berlangsug. Dengan demikian, pembelajaran dengan model inkuiri terbimbing dapat meningkatkan keterampilan proses sains peserta didik di kelas

Kata kunci: Inkuiri Terbimbing; LKPD; Keterampilan Proses Sains.
\end{abstract}

\section{ABSTRACT}

This article was based on the learning patterns that are emphasized at present, apart from demanding learning that prioritizes critical thinking skills, learning must also use a scientific approach. Most students consider that Physics, especially the sub-concept of heat, is an abstract material. For this reason, there was a need for an application in learning, namely by applying a guided inquiry model assisted by LKPD so that students can improve their science process skills. The purpose of this research was to describe the application of the guided inquiry model assisted by LKPD to improve science process skills in heat material. The method used in this writing is literature study by reviewing some of the literature to be analyzed and made conclusions. The results of the writing show that the guided inquiry model assisted by LKPD for students can be a solution to the problems encountered in improving the science process skills of students in the classroom. The LKPD-assisted guided inquiry model was applied to students in Senior High Schools with several steps, among others; students were given problems to solve, problems were given in the form of LKPD, then carried out a process of analysis and discussion to find solutions to the problems found, after that students made presentations to other groups with LKPD that have been filled during 
the learning process. Thus, learning with a guided inquiry model can improve the science process skills of students in the classroom

Keywords: Guided Inquiry; LKPD; Science Process Skills.

diunggah: 2020-03-11, direvisi: 2020-11-27, diterima: 2020-11-27, dipublikasi: 2020-11-27

Copyright (c) 2020 Aryani, S.

This is an open access article under the CC-BY license

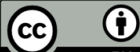

Cara sitasi: Aryani, S. D. (2021). Aplikasi model inkuiri terbimbing berbantuan lkpd untuk meningkatkan keterampilan proses sains pada materi kalor. JINoP (Jurnal Inovasi Pembelajaran), 6(2), 239-247. doi:https://doi.org/10.22219/jinop.v6i2.11490

\section{PENDAHULUAN}

Perkembangan dalam ilmu pengetahuan dan teknologi yang sangat pesat menuntut peningkatan kualitas sumber daya manusia yang siap bersaing di era globalisasi dan pasar bebas yang berdampak pada setiap aspek kehidupan. Aspek yang paling utama berpengaruh dalam mencetak sumber daya manusia yang berkualitas ini ialah salah satunya dalam aspek pendidikan.

Dalam Sanjaya (2006: 65) secara jelas dikatakan bahwa pendidikan nasional berfungsi mengembangkan kemampuan dan membentuk watak serta peradaban bangsa yang bermartabat dalam rangka mencerdaskan kehidupan bangsa, bertujuan untuk mengembangkan potensi peserta didik agar menjadi manusia yang beriman dan bertakwa kepada Tuhan Yang Maha Esa, berakhlak mulia, sehat, berilmu, cakap, kreatif, mandiri, dan menjadi warga negara yang demokratis serta bertanggung jawab

Salah satu upaya yang dilakukan pemerintah adalah mengembangkan kurikulum berbasis kompetensi pada tahun 2004 dan 2006 menjadi kurikulum 2013. Kurikulum 2013 ditetapkan sebagai bagian meningkatkan kualitas pendidikan Indonesia di seluruh jenjang yang dinilai dari tiga ranah kompetensi, yaitu: pengetahuan, sikap, dan keterampilan. Tahap pelaksanaan kurikulum 2013 berfokus pada kegiatan aktif peserta didik melalui suatu proses ilmiah dengan tujuan agar pembelajaran tidak hanya menciptakan peserta didik yang mempunyai kompetensi pengetahuan saja, tetapi juga mampu menciptakan peserta didik yang baik dalam sikap dan keterampilan menurut Kemendikbud dalam Tewa, Yuniarti \& Nurlansi (2018).

Berdasarkan Permendikbud tersebut dapat dipahami bahwa pola pembelajaran yang ditekankan saat ini selain menuntut pembelajaran yang mengedepankan kemampuan berpikir kritis juga pembelajaran harus menggunakan pendekatan saintifik. Pendekatan saintifik merupakan kerangka ilmiah pembelajaran yang diusung oleh Kurikulum 2013. Pendekatan saintifik juga merupakan pembelajaran yang mengadopsi langkah-langkah saintis yang membangun pengetahuan melalui metode ilmiah. Oleh karena itu diperlukan suatu proses pembelajaran dimana siswa dapat menggali melalui keterampilan keterampilan proses secara scientist. (Kurniawati, Desi et al. 2016).

Cara yang dapat dilakukan untuk menghasilkan masyarakat yang unggul dalam pendidikan adalah dengan melaksanakan proses pembelajaran dalam suatu kurikulum. Kurikulum yang digunakan oleh satuan sekolah menengah atas adalah kurikulum 2013. Pembelajaran dalam konteks kurikulum 2013 diorientasikan untuk menghasilkan insan Indonesia yang produktif, kreatif, inovatif, dan afektif melalui 
penguatan sikap (tahu mengapa), keterampilan (tahu bagaimana), dan pengetahuan (tahu apa) yang terintegrasi (Abidin, Yunus, 2014:17). Maka dari itu pembelajaran konteks kurikulum 2013 mengarahkan peserta didik agar mendorong mencari tahu bukan pembelajaran yang memberi tahu peserta didik, serta menunjukan bahwa pembelajaran IPA yang membekali pengetahuan saja tidak cukup, sehingga harus dilengkapi dengan berbagai macam keterampilan.

Pelaksanaan kegiatan pembelajaran perlu diterapkan dengan menggunakan model pembelajaran, karena model pembelajaran memudahkan guru untuk merencanakan suatu kegiatan pembelajaran dan membuat kegiatan pembelajaran lebih menarik bagi peserta didik sehingga tidak membosankan. Pembelajaran dalam konteks kurikulum 2013 diimplementasikan melalui aktivitas berbasis pendekatan ilmiah, menurut Asniati, Mansyur \& Tabrani Gani (2017) model pembelajaran dengan pendekatan ilmiah dalam kurikulum 2013 terdiri atas discovery, inquiry, problem based learning, dan project based learning. Dari beberapa model pembelajaran tersebut, kenyataan pelaksanaan di lapangan guru belum sepenuhnya mengaplikasikan model pembelajaran yang sesuai dengan pendekatan ilmiah dalam kegiatan belajar mengajar di kelas, meskipun model pembelajaran yang digunakan sudah sesuai dengan kriteria kurikulum 2013, namun dalam pelaksanaannya langkah-langkah dalam model pembelajaran tersebut belum terlaksana dengan sesuai, serta pembelajaran IPA memerlukan pengembangan keterampilan yakni keterampilan proses sains.

Salah satu inovasi dalam belajar yang dapat mengarahkan peserta didik memperoleh pemahaman konsep yang mendalam dan bermakna adalah pembelajaran berbasis inkuiri. Pembelajaran Inkuiri lebih memusatkan kepada pemahaman peserta didik menemukan konsep, sehingga peserta didik mampu menemukan sendiri bagaiamana konsep itu ada dan dapat digunakan (Justice, dkk, 2009).

Menurut Memes (dikutip dalam Muhammad Minan Chusni, 2016), Fisika merupakan bagian dari sains dan termasuk mata pelajaran yang di ajarkan di sekolah. Sesuai dengan karakteristik fisika, maka implikasinya dalam proses pembelajaran digunakan pendekatan dan metode yang sesuai untuk memantapkan penguasaan berbagai konsep fisika dan penerapanya dalam kehidupan sehari-hari kepada peserta didik. Seringkali dijumpai pendapat dari peserta didik, bahwa fisika merupakan mata pelajaran yang dianggap sulit, terbukti dengan nilai UTS, UAS dan dari loporan hasil belajar fisika peserta didik cenderung lebih rendah dibandingkan dengan mata pelajaran yang lain.

Faktor yang mempengaruhi kesulitan pembelajaran fisika selama ini karena pembelajaran tidak diarahkan untuk menangkap makna yang terkandung dan mengaplikasikan-nya dalam kehidupan sehari-hari. Oleh karena itu, peran seorang guru menjadi sangat penting dalam menciptakan situasi, menyediakan kemudahan, membimbing, dan memberi pengarahan sehingga peserta didik dapat melakukan proses pembelajaran dengan maksimal dan akhirnya memperoleh hasil belajar yang positif. (Djamarah, dalam Muhammad Minan Chusni, 2016).

Hukum kalor merupakan salah satu konsep dalam pembelajaran fisika yang memerlukan penemuan langsung oleh peserta didik. Pada kenyataannya banyak guru yang menerapkan metode ceramah padahal konsep ini mampu ditemukan secara penemuan langsung. Praktikum subkonsep kalor sangat sesuai dengan materi 
pelajaran dikelas, namun kurang layak dikerjakan individu dikarenakan kurangnya waktu yang tersedia.

Berdasarkan pemaparan diatas, peneliti melakukan penelitian studi pustaka mengenai pembelajaran kalor berbantuan LKPD dengan mengaplikasikan model pembelajaran yang digunakan yaitu inkuiri terbimbing, dengan harapan mengetahui aplikasi model pembelajaran inkuiri terbimbing berbantuan lkpd untuk meningkatkan keterampilan proses sains

\section{METODE}

Metode yang digunakan dalam penulisan ini berupa studi kepustakan. Data dikumpulkan untuk dianalisis kemudian disajikan dalam hasil dan pembahasan agar dapat dibuat kesimpulan. Data yang diperoleh dari penelitian berupa presentase penelitian jurnal relevan mengenai aplikasi model pembelajaran inkuiri terbimbing berbantuan LKPD dalam meningkatkan keterampilan proses sains peserta didik yang diperoleh melalui kajian studi pustaka. Studi pustaka yang dilakukan adalah dengan mengukur dan mempresentasikan keterampilan proses sains peserta didik melalui beberapa jurnal penelitian relevan yang membahas tentang pengaruh model inkuiri terbimbing yang menggunakan LKPD untuk meningkatkan keterampilan proses sains dengan bebrapa jurnal relevan lainnya.

\section{HASIL DAN PEMBAHASAN \\ Inkuiri Terbimbing}

Ada banyak tokoh yang menjelaskan mengenai pembelajaran inkuiri terbimbing diantaranya adalah Bonnstetter (Wisudawati, Asih W dan Eka Sulistyowati, 2017:84) mengatakan "Pada tingkat ini peserta didik diberi kesempatan untuk merumuskan prosedur praktikum, menganalisis hasil, dan membuat kesimpulan. Sedangkan dalam menentukan topik, pertanyaan, serta alat dan bahan praktikum guru hanya sebagai fasilitator". Penjelasan lain mengenai pembelajaran inkuiri terbimbing dikemukakan oleh Hamalik (Priansa, Donni. J, 2017:265) menyatakan bahwa inkuiri terbimbing melibatkan peserta didik dalam menjawab pertanyaan-pertanyaan guru, dalam pelaksanaannya peserta didik melakukan penemuan sedangkan guru membimbing dan mengarahkan kepada yang benar. Setelah mengetahui pengertian mengenai model pembelajaran inkuiri terbimbing, terdapat beberapa langkah-langkah dari model pembelajaran inkuiri terbimbing yakni menyajikan masalah; mengumpulkan dan verifikasi data; melakukan eksperimen; mengorganisasikan dan membuat penjelasan; membuat kesimpulan. Menurut isroka'tun dan Amelia (2018) langkah-langkah pembelajaran inkuiri terbimbing sebagai berikut:

\section{Tabel 1. Langkah Pembelajaran Inkuiri Terbimbing}

\begin{tabular}{|c|c|}
\hline Fase & Perilaku Guru \\
\hline Merumuskan masalah & $\begin{array}{l}\text { Guru membimbing siswa mengidentifikasi masalah dalam LKPD. } \\
\text { Guru membagi peserta didik dalam kelompok. }\end{array}$ \\
\hline Merumuskan Hipotesis & $\begin{array}{l}\text { Guru memberikan kesempatan pada peserta didik untuk memberikan } \\
\text { pendapat dalam bentuk hipotesis. }\end{array}$ \\
\hline Mengumpulkan Data & Guru membimbing peserta didik untuk melakukan study literature \\
\hline Menguji Hipotesis & Peserta didik melakukan pengolahan data \\
\hline Menarik kesimpulan & Peserta didik melaukan penarikan hasil dan kesimpulan percobaan \\
\hline
\end{tabular}




\section{LKPD}

Media pembelajaran adalah suatu alat yang digunakan untuk memermudah peserta didik dalam memahami pelajaran. Salah satu media yang digunakan untuk memberi bantuan pada peserta didik dan dapat meningkatkan aktivitas belajar di kelas yaitu Lembar Kerja Peserta didik (LKPD). LKPD memberi bantuan berupa rangkaian susunan pembelajaran yang akan mereka pelajari dengan menekankan pada aspek-aspek tertentu sehingga dapat meningkatkan aktivitas yang berupa keterampilan dalam proses pembelajaran (Choo, S.S.Y., dan Rotgans dalam Desi Kurniawati Et al. 2016). Meningkatnya keterampilan proses akan berpengaruh kepada kegiatan peserta didik untuk menggali materi pelajaran fisika khususnya pada materi kalor dengan langkah-langkah ilmiah seperti mengamati, bertanya, mengeksplorasi dan lain sebagainya. Kolaborasi yang cocok dalam penggunaan model pembelajaran inkuiri terbimbing ditunjang dengan media pembelajaran yaitu menggunakan LKPD, sehingga diharapkan keterampilan proses sains pesera didik akan meningkat dengan adanya aktivitas dalam menemukan konsep yang dilakukan berdasarkan langkah-langkah ilmiah

\section{Keterampilan Proses Sains}

Keterampilan proses sains merupakan keterampilan yang harus dikembangkan pada diri peserta didik, hal ini bertujuan untuk melatih kemampuan berfikir, kemampuan keterampilan dalam mengambil keputusan, keputusan dalam bersosialisasi dan lain sebagainya. Keterampilan proses sains merupakan salah satu dari keterampilan-keterampilan yang diperlukan oleh seorang peserta didik untuk dapat mengembangkan potensi dirinya (Handayani et al. dalam Saidaturrahmi, 2019). Peserta didik penting untuk memiliki keterampilan proses sains karena ilmu pengetahuan berkembang dengan cepat dan tidak bersifat mutlak, sehingga peserta didik terbiasa untuk menggali dan memperbarui pengetahuannya berdasarkan pengalaman (Puspita et al. dalam Saidaturrahmi, 2019).

Kriteria pencapaian suatu keterampilan proses sains tentunya terdiri dari berbagai indikator, agar mudah dalam pengukuran keterampilan tersebut. Adapun indikator keterampilan proses sains menurut Tawil dan Liliasari (2014), pada tabel 2 sebagai berikut:

Tabel 2. Indikator Keterampilan Proses Sains

\begin{tabular}{ll}
\hline $\begin{array}{l}\text { Aspek Keterampilan Proses } \\
\text { Sains }\end{array}$ & Indikator \\
\hline Mengamati/observasi & $\begin{array}{l}\text { Menggunakan indera; } \\
\text { mengumpulkan/menggunakan fakta yang relevan }\end{array}$ \\
Mengelompokkan/klasifikasi & $\begin{array}{l}\text { Mencatat setiap pengamatan secara terpisah; } \\
\text { mencari perbedaan, persamaan; mengontraskan } \\
\text { ciri-ciri membandingkan; mencari dasar }\end{array}$ \\
& pengelompokkan atau penggolongan \\
& $\begin{array}{l}\text { Menghubung-hubungkan hasil pengamatan; } \\
\text { menemukan pola/keteraturan dalam suatu seri }\end{array}$ \\
pengafsirkan/interpretasi & $\begin{array}{l}\text { Menggunakan pola-pola atau keter-aturan hasil } \\
\text { pengamatan; mengemukakan apa yang mungkin } \\
\text { terjadi pada keadaan yang belum terjadi }\end{array}$
\end{tabular}


Melakukan komunikasi

Mengajukan pertanyaan

Mengajukan hipotesis

Merencanakan percobaan/penyelidikan

Menggunakan alat/bahan/sumber

Menerapkan konsep

Melaksanakan percobaan/penyelidikan

Mendeskripsikan atau menggambarkan data empiris hasil percobaan/pengamatan dengan grafik/tabel/diagram atau mengubahnya dalam bentuk salah satunya; menyusun dan menyampaikan laporan secara sistematis dan jelas; menjelaskan hasil percobaan/penyelidikan; membaca grafik atau tabel atau diagram; mendiskusikan hasil kegiatan suat masalah/peristiwa

Bertanya apa, bagaimana dan mengapa; bertanya untuk meminta penjelasan; mengajukan pertanyaan yang berlatar belakang hipotesis

Mengetahui bahwa ada lebih dari suatu kemungkinan penjelasan dari suatu kejadian; menyadari bahwa suatu penjelasan perlu diuji kebenarannya dengan memperoleh bukti lebih banyak atau melakukan cara pemecahan masalah Menentukan alat, bahan, atau sumber yang akan digunakan; menentukan variabel atau faktor-faktor penentu; menentukan apa yang akan diatur, diamati, dicatat; menentukan apa yang akan dilaksanakan berupa langkah kerja

Memakai alat dan atau bahan atau sumber; mengetahui alasan mengapa menggunakan alat atau bahan/sumber

Menggunakan konsep/prinsip yang telah dipelajari dalam situasi baru; menggunakan konsep/prinsip pada pengalaman baru untuk menjelaskan apa yang sedang terjadi

Penilaian proses dan hasil belajar IPA menurut teknik dan cara-cara penilaian yang lebih komprehensif (Stiggins, 1994). Di samping aspek hasil belajar yang dinilai harus menyelruh yaitu aspek kognitif, afektif dan psikomotor, teknik penilaian dan instrumen penilaian seyogiyanya lebih bervariasi. Hasil belajar dapat dibedakan menjadi pengetahuan (knowledge), penalaran (reasoning), keterampilan (skills), hasil karya (product) dan afektif (affective).

Sumber: Tawil dan Liliasari (2014)

\section{Aplikasi model inkuiri terbimbing berbantuan lkpd untuk meningkatkan keterampilan proses sains pada materi kalor}

Model pembelajaran inkuiri terbimbing di aplikasikan karena peserta didik kurang berpengalaman belajar dengan secara mandiri. Dalam inkuiri terbimbing, guru memberikan bimbingan dan petunjuk yang cukup luas kepada peserta didik sehingga peserta didik tidak dilepas begitu saja dalam proses belajar mengajar. Dengan demikian, proses belajar mengajar akan lebih terarah dan tepat sasaran. 
Pemilihan masalah dilakukan oleh guru tetapi penemuan konsep dilakukan oleh peserta didik dengan cara guru memberikan banyak pertanyaan pada peserta didik yang mengarah pada penemuan konsep. Sebagian besar perencanaan dibuat oleh guru. Peserta didik melakukan pengamatan dan pengukuran untuk memperoleh data tertentu. Peserta didik belajar lebih berorientasi pada bimbingan dan petunjuk dari guru hingga peserta didik dapat memahami konsep-konsep pelajaran. Model pembelajaran ini akan menghadapkan peserta didik pada tugas-tugas yang relevan untuk diselesaikan baik melalui individual maupun secara diskusi kelompok agar mampu menyelesaikan masalah dan menarik suatu kesimpulan secara mandiri (Alhuday, M Taufiq Et al, 2018).

Model pembelajaran inkuiri terbimbing terdapat langkah menguji hipotesis sehingga mengarahkan peserta didik untuk melakukan suatu percobaan dan dapat menemukan pengetahuan secara mandiri. Model pembelajaran inkuiri terbimbing membekali keterampilan-keterampilan proses sains, sehingga guru akan dengan mudah mengukur keterampilan proses sains saat pelaksanaan pembelajaran menurut Anam, Khoirul (2017).

Dalam jurnal Agus Budioyono dan Hartini (2016) menyatakan bahwa inkuiri terbimbing memberikan keterlibatan peserta didik untuk aktif dalam KPS. Selain itu KPS dilakukan siswa selama pembelajaran. Hal ini sejalan dengan karekteristik sains yang berhubungan dengan cara mengetahui sesuatu bukan hanya fakta dan konsep aja tetapi menekankan pada penemuan-penuan seperti yang dilakukan oleh para saintis terdahulu. Dalam jurnal Chusni, M Minan Vol. 01 menyatakan bahwa model inkuiri terbimbing mampu mempengaruhi keterampilan proses sains sehingga model tesebut tepat digunakan dalam pembelajaran.

Dalam jurnal Tewa, Yuniarti \& Nurlansi menyatakan bahwa model inkuiri terbimbing tepat digunakan dalam materi oksidasi dan dapat meningkatkan keterampilan proses sains siswa, dan diperkuat dalam jurnal Kurniawati, Desi. Et al menyatakan hal yang mendasar sama bahwasannya model inkuiri dapat mempengaruhi keterampilan proses sains siswa. Hal tersebut juga dinyatakan oleh Justice, C., Rice, J., Roy, D., Hudspith, B., \& Jenkins, H. (2009), Alhudaya, M Taufiq Et al. (2018).

Diperkuat dengan pernyataan bahwa penerapan model pembelajaran inkuiri terbimbing dilengkapi LKS dapat meningkatkan keterampilan proses sains dan prestasi belajar siswa kelas X MIA 4 SMA N 1 Karanganyar Hal ini dapat dikarenakan dalam pembelajaran inkuiri terbimbing menekankan suatu proses pembelajaran dengan menggunakan langkah-langkah ilmiah yang ada dalam keterampilan proses sains sehingga konsep pada materi pelajaran dapat terbentuk dengan baik. Selain itu dengan penerapan model inkuiri terbimbing maka keterampilan proses sains akan meningkat sehingga pembelajaran di dalam kelas lebih aktif, melalui pembelajaran dengan penemuan konsep maka siswa lebih dapat memahami materi, sedemikian hingga dapat meningkatkan prestasi belajar (Kurniawati. Et al. (2016).

Berdasarkan penelitian kajian pustaka yang telah dilakukan sebelumnya dapat diketahui bahwa pelaksanaan pembelajaran menggunakan model pembelajaran inkuiri terbimbing berbantuan LKPD dapat meningkatkan keterampilan proses sains ditunjukkan pada tabel 3. 
Tabel 3. Studi pustaka jurnal

\begin{tabular}{llll}
\hline & & $100 \%$ & \\
\cline { 3 - 3 } Jurnal penelitian & Setuju & Tidak setuju & Skor \\
\hline 10 jurnal relevan & - & $100 \%$
\end{tabular}

Berdasarkan tabel diatas dapat dilihat bahwasannya setelah peneliti melakukan kajian pustaka menunjukkan hampir keseluruhan jurnal penelitian yang relevan menyatakan bahwa inkuiri terbimbing dengan berbantuan LKPD sangat berpengaruh dalam meningkatkan keterampilan proses sains peserta didik.

\section{SIMPULAN}

Dari berbagai pembahasan yang telah dijabarkan dapat ditarik kesimpulan dan dimaknai bahwa model pembelajaran inkuiri terbimbing berbantuan LKPD dapat meningkatkan keterampilan proses sains peserta didik. Kesesuaian peserta didik dalam melakukan metode ilmiah dapat berpengaruh pada peningkatan keterampilan proses sains peserta didik dicapai sehingga perlunya keprofesionalan guru sebagai pengajar agar dapat menjadikan peserta didik mampu melakukan analisis ilmiag dan ketrampilan proses sains yang lebih baik,

\section{DAFTAR PUSTAKA}

Abidin, Y. (2014). Desain Sistem Pembelajaran dalam Konteks Kurikulum 2013. Bandung: PT Refika aditama.

Alhudaya, M. T. (2018). Pengaruh Inkuiri Terbimbing terhadap Keterampilan Proses Sains dan Pemahaman Konsep Optik Siswa Kelas VIII. Jurnal Pendidikan: Teori, Penelitian, dan Pengembangan Volume: 3 Nomor: 11

Anam, K. (2017). Pembelajaran Berbasis Inkuiri, Metode dan Aplikasi. Yogyakarta: Pustaka Pelajar.

Asniati, M dan Tabrani G. (2017). "Analisis Kompetensi Guru Kimia dalam Mengimplementasikan Model Pembelajaran Berbasis Kurikulum 2013 di SMK SMAK Makassar". Chemistry Education Review (CER), (1), 01-12.

Chusni, M M. (2016). Studi komparatif pendekatan verifikasi dan pendekatan inkuiri terbimbing terhadap kognitif siswa smp pada materi pesawat sederhana. Jurnal EduFisika Vol. 01 No. 02.

Justice, C., Rice, J., Roy, D., Hudspith, B., \& Jenkins, H. (2009). Inquiry-Based Learning In Higher Education: Administrators' Perspectives On Integrating Inquiry Pedagogy Into The Curriculum. Higher Education, 58

Kurniawati, D.. (2016). Penerapan model pembelajaran inkuiri terbimbing dilengkapi lks untuk meningkatkan keterampilan proses sains dan prestasi belajar pada materi pokok hukum dasar kimia siswa kelas x mia 4 sma $n 1$ karanganyar tahun pelajaran 2014/2015. Jurnal Pendidikan Kimia (JPK), Vol. 5 No. 1.

Priansa, D. J. (2017). Pengembangan Strategi dan Model Pembelajaran (Inovatif, Kreatif, dan Prestatif Dalam Memahami Peserta Didik). Bandung: CV Pustaka Setia.

Putri, N. A.. (2015). "Perbedaan Model Pembelajaran Open Inquiry dan Guided Inquiry Berdasarkan Kemandirian Belajar dan Berfikir Tingkat Tinggi pada 
Mata Pelajaran Biologi Kelas 11 MAN Tempursari-Ngawi. Jurnal Pendidikan Biologi Indonesia, 1(1).

Rosmalia, A dan Isroka'tun. (2018). Model -Model Pembelajaran Matematika. Jakarta: PT Bumi Aksara

Saidaturrahmi. (2019). Penerapan Lembar Kerja Peserta Didik Inkuiri Terbimbing Terhadap Keterampilan Proses Sains Peserta Didik. Jurnal Pendidikan Sains Indonesia (Indonesian Journal of Science Education), Vol. 07, No.01

Sanjaya, W. (2006), pembelajaran dalam Implementasi Kurikulum Berbasis Kompetensi. Jakarta: Kencana Prenada Media Grup

Tewa, Y \& Nurlansi. (2018). Perbandingan model pembelajaran inkuiri terbimbing dengan inkuiri terstruktur terhadap peningkatan pemahaman konsep reaksi oksidasireduksi (redoks) pada siswa sma negeri 1 kaledupa. Jurnal Gema Pendidikan Vol. 25 Nomor 2.

Tawil, M., dan Liliasari. (2014). Keterampilan-Keterampilan Sains dan Implementasinya Dalam Pembelajaran IPA. Makassar: Badan Penerbit Universitas Negeri Makassar.

Wisudawati, A. W., dan Sulistyowati, E. (2017). Metodologi Pembelajaran IPA. Jakarta: Bumi Aksara. 